\title{
Nicotinamide Is a Potent Inducer of Endocrine Differentiation in Cultured Human Fetal Pancreatic Cells
}

\author{
Timo Otonkoski, * Gillian M. Beattie, " Martin I. Mally, * Camillo Ricordi, ${ }^{\star}$ and Alberto Hayek * \\ *The Lucy Thorne Whittier Children's Center, The Whittier Institute for Diabetes and Endocrinology, La Jolla, California 92037 ; \\ and $\ddagger$ University of Pittsburgh Transplant Institute, Pittsburgh, Pennsylvania 15260
}

\begin{abstract}
The effects of nicotinamide (NIC) on human fetal and adult endocrine pancreatic cells were studied in tissue culture. Treatment of the fetal cells with $10 \mathrm{mM}$ NIC resulted in a twofold increase in DNA content and a threefold increase in insulin content. This was associated with the development of $\beta$ cell outgrowths from undifferentiated epithelial cell clusters and an increase in the expression of the insulin, glacagon, and somatostatin genes. DNA synthesis was stimulated only in the undifferentiated cells. Half-maximal doses for the insulinotropic and mitogenic effects of NIC were 5-10 and 1-2 mM, respectively. Islet-like cell clusters cultured with NIC responded to glucose stimulation with a biphasic increase in insulin release (fourfold peak), whereas control cells were unresponsive to glucose. Both control and NIC-treated cells developed into functional islet tissue after transplantation into athymic nude mice. As compared with adult islets, the insulinotropic action of NIC could only be demonstrated in the fetal cells. Our results indicate that NIC induces differentiation and maturation of human fetal pancreatic islet cells. This model should be useful for the study of molecular mechanisms involved in $\beta$ cell development. (J. Clin. Invest. 1993. 92:1459-1466.) Key words: islets of Langerhans • nicotinamide $\bullet$ tissue culture • cell differentiation • transplantation
\end{abstract}

\section{Introduction}

Nicotinamide (NIC) ${ }^{1}$ treatment prevents the development of diabetes in experimental animals following administration of the $\beta$ cell toxins streptozotocin and alloxan (1), as well as the spontaneous diabetes of NOD mice (2). The mechanism of this effect has been attributed to inhibition of the nuclear enzyme poly(ADP-ribose) synthetase which, if activated during DNA repair synthesis, could lead to a critical decrease in the

Parts of this work were presented at the 52nd Annual Meeting of the American Diabetes Association, San Antonio, TX, 20-23 June 1992, and have appeared in abstract form (1992. Diabetes. 41[Suppl. 1]:159A).

Address correspondence and reprint requests to Timo Otonkoski, M.D., The Whittier Institute for Diabetes and Endocrinology, 9894 Genesee Avenue, La Jolla, CA 92037.

Received for publication 20 January 1993 and in revised form 9 April 1993.

1. Abbreviations used in this paper: BrdU, bromodeoxyuridine; ICC, islet-like cell cluster; NIC, nicotinamide; nt, nucleotides.

J. Clin. Invest.

(c) The American Society for Clinical Investigation, Inc.

0021-9738/93/09/1459/08 \$2.00

Volume 92, September 1993, 1459-1466
NAD level of the $\beta$ cells ( 3 ). Other mechanisms, however, may be operative such as free oxygen radical scavenging (4) and inhibition of MHC class II antigen expression on the islet cells (5). NIC also enhances the recovery from diabetes after $90 \%$ pancreatectomy both in rats (6) and dogs (7), suggesting a stimulatory effect on islet regeneration. Further studies have confirmed that NIC promotes replication of mouse islet cells both in culture (8) and after transplantation (9). The only other study addressing the effects of NIC on human islets showed a stimulatory effect on the formation of islet-like cell clusters (ICC) in human fetal pancreatic cultures (10).

Although the results of clinical trials using NIC in newly diagnosed type 1 diabetic patients have not been encouraging (11-13), recent experience in prediabetic individuals suggests that, when started early enough in the course of the disease, NIC administration may delay or prevent the development of type I diabetes (14). These observations have promoted several prospective clinical studies that are currently in progress (15). Considering the many potent actions of NIC on pancreatic islet cells in animal models, as well as its use in clinical trials to preserve $\beta$ cell function, we have characterized the effects of NIC on the function, growth, and differentiation of human islets.

\section{Methods}

Tissue culture. Human fetal pancreases at 18-24 gestational weeks were obtained through nonprofit organ procurement centers (Advanced Bioscience Resources, Oakland, CA, and International Institute for the Advancement of Medicine, Exton, PA ). Patient consent for tissue donation was obtained by the procurement centers. In addition, our own Institutional Review Board had reviewed and approved the use of fetal tissue for these studies. The pancreases, obtained by dilatation and extraction, were shipped on ice in RPMI 1640 medium (Irvine Scientific, Irvine, CA) containing $10 \%$ pooled normal human serum and antibiotics ( $100 \mathrm{U} / \mathrm{ml}$ penicillin, $0.1 \mathrm{mg} / \mathrm{ml}$ streptomycin, and $1 \mu \mathrm{g} / \mathrm{ml}$ amphotericin B) and received in the laboratory within 18-24 h. Digestion and culture of the tissue was carried out essentially as described previously (16). Briefly, the pancreases were dissected free of surrounding tissue, weighed, and cut into $1-\mathrm{mm}^{3}$ pieces. After washing in HBSS containing $10 \mathrm{mM}$ Hepes (Sigma Immunochemicals, St. Louis, MO), the fragments were digested for $15 \mathrm{~min}$ in a shaking water bath $\left(37^{\circ} \mathrm{C}, 200\right.$ oscillations $\left./ \mathrm{min}\right)$ in HBSS containing $5.5 \mathrm{mg} / \mathrm{ml}$ collagenase $\mathbf{P}$ (Boehringer Mannheim Biochemicals, Indianapolis, IN). Digested tissue was washed twice in cold HBSS and plated on 60-mm petri dishes (diSPo; Baxter, McGaw Park, IL) in RPMI 1640 supplemented with $10 \%$ human serum and antibiotics. Various concentrations of NIC (Sigma Immunochemicals) were added to the culture medium from the beginning. The NIC content of the standard medium without additions was $8 \mu \mathrm{M}$. Medium was changed on the 4 th $d$ of culture and every 2-3d thereafter. ICCs were harvested from the dishes after 4-11 d. To detect possible cytotoxic effects, lactate dehydrogenase activity was measured in the culture medium with a commercial kit (Sigma Immunochemicals). 
For monolayer culture, ICCs were transferred to tissue culture dishes coated with bovine corneal endothelial cell matrix as described previously (17). Nonattached cells were removed after $3 \mathrm{~d}$.

Adult human islets were isolated with an automated method as described previously (18) and shipped on ice. Dithizone staining was used to determine the purity of the islet preparations (19). The same method was used to detect insulin-containing cells in the fetal ICCs.

To quantitate the effect of NIC on the development of ICCs and the $\beta$ cell mass after $7 \mathrm{~d}$ in culture, pieces of 10 consecutive pancreases were blotted with filter paper to remove excess moisture, weighed, and treated as above. After $7 \mathrm{~d}$, all ICCs were harvested and counted, and the results were correlated to the original tissue weight.

Immunohistochemistry. ICCs were incubated for $16 \mathrm{~h}$ with $0.1 \mathrm{mM}$ bromodeoxyuridine (BrdU), fixed in $4 \%$ paraformaldehyde, and embedded in paraffin. $10-\mu \mathrm{m}$ sections were stained using the immunoalkaline phosphatase technique (20) for insulin, glucagon and somatostatin and the immunoperoxidase technique (21) for BrdU. Polyclonal guinea pig antiporcine insulin (dilution 1:100) (Chemicon, El Segundo, CA), rabbit antiglucagon (1:250) and rabbit antisomatostatin (1:150) (Biogenex Labs, San Ramon, CA) antibodies were used. Cell nuclei which had incorporated BrdU during DNA synthesis were identified by binding of mouse monoclonal anti-BrdU ( $1: 20)$ (Dako, Carpintaria, CA). The surface area of insulin positive cells, as percent of the total ICC area, was quantitated with a computerized image analyzer (American Innovision, San Diego, CA). The same method was used for the determination of BrdU labeling index.

DNA synthesis and insulin secretion. After various incubation times in culture, ICCs were harvested in groups of 50 into $35-\mathrm{mm}$ petri dishes in $1 \mathrm{ml}$ of medium containing $1 \mu \mathrm{Ci}$ of [methyl- ${ }^{3} \mathrm{H}$ ] thymidine (specific activity $5.0 \mathrm{Ci} / \mathrm{mmol}$, Amersham Corp., Arlington, IL). After an overnight $(16-\mathrm{h})$ incubation at $37^{\circ} \mathrm{C}$ the medium was collected for insulin measurements by a solid-phase RIA (Diagnostic Products Corp., Los Angeles, CA). The ICCs were washed twice in PBS, pH 7.4, resuspended in $300 \mu \mathrm{l}$ of distilled water, and homogenized by sonication. DNA was measured from the sonicate fluorometrically as described (22). Insulin content was measured by RIA in dilutions $(\geq 1: 20)$ of acid ethanol extracts. Incorporation of $\left[{ }^{3} \mathrm{H}\right]$ thymidine was determined by trapping $10 \%$ trichloroacetic acid precipitates of the sonicates on glass fiber filters (Whatman GF/A, Maidstone, United Kingdom), drying, and liquid scintillation counting in $4 \mathrm{ml}$ of BetaMax (ICN, Irvine, CA).

Insulin release in response to glucose and glucose plus theophylline was studied by perifusion as described previously (23). After $7 \mathrm{~d}$ in culture, batches of 300-400 ICCs were loaded in perifusion chambers filled with Bio-Gel P2 (Bio-Rad Laboratories, Richmond, CA) microbeads. Krebs-Ringer bicarbonate buffer supplemented with $20 \mathrm{mM}$ Hepes, $\mathrm{pH} 7.40$, and $0.2 \%$ bovine serum albumin was pumped through the chambers at $0.25 \mathrm{ml} / \mathrm{min}$. Up to six chambers were perifused simultaneously (Superfusion 600; Brandel, Gaithersburg, MD).

Islet hormone gene expression. Islet hormone mRNA levels were measured with a ribonuclease protection assay (24). Total RNA was isolated (25) from fetal ICCs cultured in the absence or presence of 10 $\mathrm{mM}$ NIC for $7 \mathrm{~d}$. RNA ( $400 \mathrm{ng}$ ) was hybridized for $18 \mathrm{~h}$ at $56^{\circ} \mathrm{C}$ with ${ }^{32} \mathrm{P}$-radiolabeled antisense probes specific for human insulin (262 nucleotides [nt], cDNA probe provided by Dr. P. Miettinen, University of Helsinki, Finland), glucagon ( $389 \mathrm{nt}$, cDNA provided by Dr. D. Drucker, Toronto General Hospital, Toronto, Ontario, Canada), or somatostatin ( $236 \mathrm{nt}$, a subclone from the genomic sequence obtained from American Type Culture Collection, Rockville, MD). Excess probe and nonhomologous RNA sequences were removed by ribonuclease digestion. The protected, double-stranded hybrids were separated by denaturing PAGE, followed by autoradiography to visualize the target RNAs. Cyclophilin (135 nt, cDNA provided by Dr. D. Bergsma, SmithKline Beecham Pharmaceuticals, King of Prussia, PA) was used as an internal quantitative probe to ensure equivalent RNA sampling. Probe-specific mRNA signals were quantitated by scanning densitometry (Ultroscan; LKB Instruments Inc., Bromma, Sweden), and normalized to the cyclophilin signal. Yeast transfer RNA (10 $\mu \mathrm{g})$ was used as a negative control. To allow for direct quantitation between transcript levels, riboprobes were adjusted to 1,000 (insulin, glucagon, and somatostatin) or 3,000 (cyclophilin) $\mathrm{cpm}$ per probe-specific uridine residue per microliter.

Transplantation studies. 500 ICCs, cultured either in standard or 10 $\mathrm{mM}$ NIC medium for $7 \mathrm{~d}$, were transplanted under the left kidney capsule of 6-wk-old athymic nude (nu/nu) BALB/C mice. Five mice were transplanted in each experimental group. After 3 mo, fasted mice were given glucose intraperitoneally $(3 \mathrm{~g} / \mathrm{kg})$ to release human $C$ peptide, which was measured with an RIA that does not cross-react with mouse $C$ peptide (DPC). After obtaining blood samples at $\mathbf{0}$ and $\mathbf{3 0}$ min, the animals were sacrificed and the grafts removed for histological analysis.

Statistics. Statistical significances of observed differences were tested with software for the MacIntosh (Statview II; Abacus Concepts, Berkeley, CA). Student's unpaired $t$ test was used when only two groups were involved, and the variation of data was close to normal. Mann-Whitney $U$ test was used when the data were skewed. Multiple comparisons were done with one-way ANOVA and Fischer's protected least significance difference (PLSD) test using 95\% level as the limit of significance.

\section{Results}

Culture characteristics. The digested tissue stayed free floating in the form of numerous small cell clusters of $30-200 \mu \mathrm{m}$ in diameter (ICCs). The number of ICCs increased during the first $4 \mathrm{~d}$ in culture. In the control medium the ICCs remained rounded and regularly shaped. In contrast, when cultured in medium containing $10 \mathrm{mM}$ NIC, several small outgrowths were seen after $4 \mathrm{~d}$. When stained with dithizone, the majority of the cells within these buds were positive, indicating the presence of insulin-containing cells (Fig. 1). In the control cultures, dithizone staining was seen weakly in small areas within the ICCs, and budding cells were rare. When the ICCs were plated on extracellular matrix-coated dishes, the majority of them attached and spread out, forming monolayers as previously described (17). During the first $7 \mathrm{~d}$, the monolayers consisted mainly of epithelioid cells, but fibroblast overgrowth occurred when the cultures were continued. This was more obvious in the presence of $10 \mathrm{mM}$ NIC.

$10 \mathrm{mM}$ NIC induced a $48 \%$ increase in the number of ICCs developing during culture. The DNA content of the individual ICCs was not significantly affected. As a result, the total DNA content of the 7-d cultured tissue was increased 2.1-fold. In comparison, the total insulin content was increased 3.3-fold, suggesting preferential development, or survival, of $\beta$ cells ( Table I).

When stained for the pancreatic hormones after $7 \mathrm{~d}$ in culture with $10 \mathrm{mM} \mathrm{NIC}$, the majority of the outgrowing cells stained positively for insulin. Many BrdU-labeled cells were also present within the ICCs. As a rule, the hormone-positive cells were BrdU-negative (Fig. 1). Only occasional cells positive for both insulin and BrdU were detected in both controls and NIC-treated cultures. In four separate experiments, the mean labeling index for BrdU-positive nuclei was three times higher in NIC-treated cultures as compared with the controls ( 3.6 vs $1.2 \%, P<0.01$ ). In the same tissue sections, there was also a threefold increase in the cell surface area covered by insulin-positive cells ( 9.3 vs $3.1 \%, P<0.01$, Fig. 2$)$.

Insulin concentrations measured in the culture medium between 4 and $13 \mathrm{~d}$ were significantly higher at all time points in the presence of $10 \mathrm{mM}$ NIC. This difference was probably not caused by leakage from damaged cells, since the simulta- 

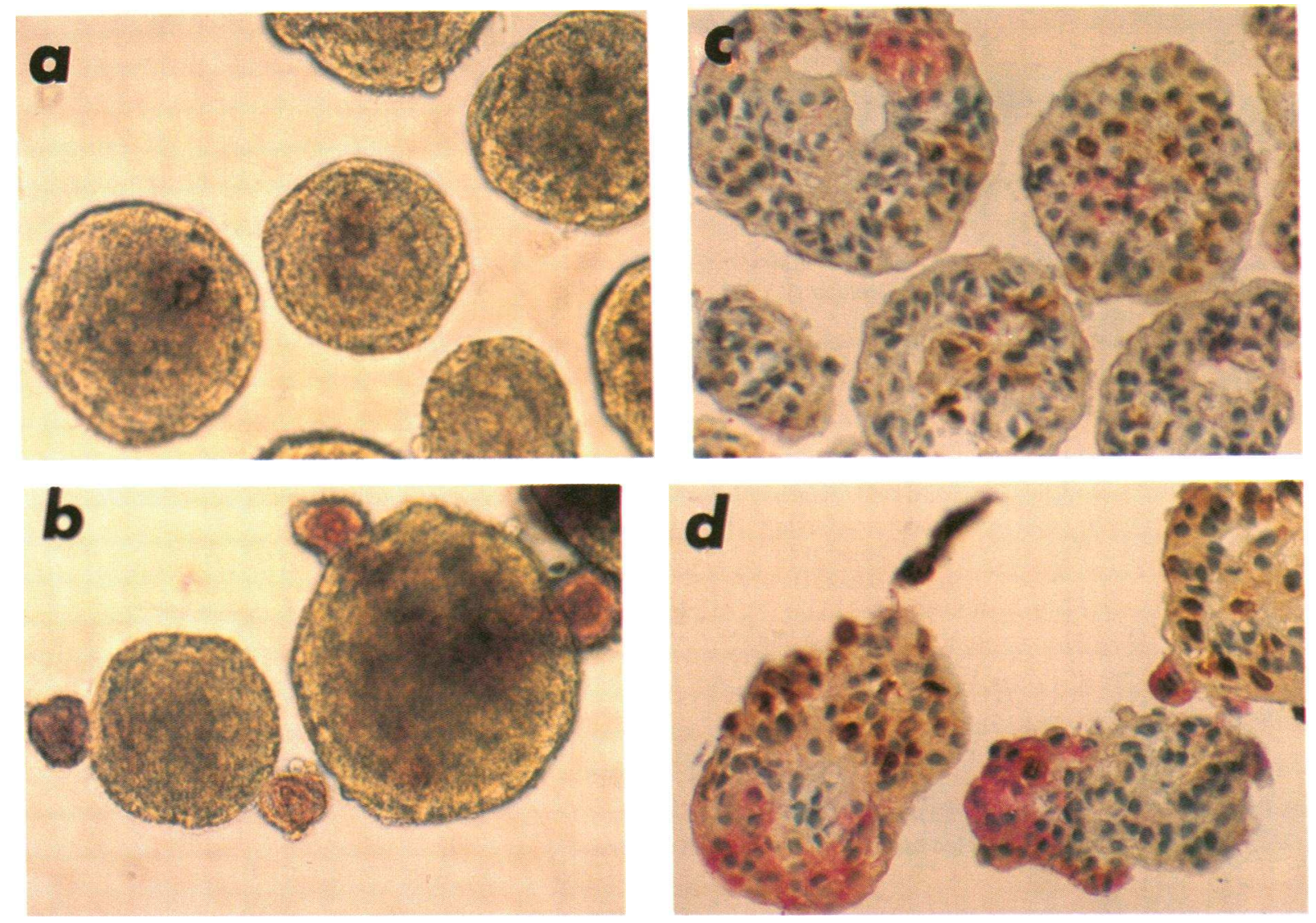

Figure 1. Dithizone staining of human fetal ICCs cultured for $7 \mathrm{~d}$ in control medium $(A)$ or medium containing $10 \mathrm{mM}$ NIC $(B)$. Positively stained (red) cells are budding out from the NIC-treated ICCs, whereas only weakly positive cells can be seen within the control ICCs. ( $C$ and $D$ ) Sections of 7-d cultured ICCs from a 22-wk pancreas stained immunohistochemically for insulin (pink) and BrdU (dark brown). (C) Cultured in standard medium; $(D)$ cultured with $10 \mathrm{mM}$ NIC. Increased BrdU labeling and outgrowths of insulin-positive cells are evident in the NIC-treated ICCs. The cells that have incorporated BrdU during the 16-h incubation do not contain insulin $(A$ and $B, \times 306 ; C$ and $D, \times 733)$.

neously measured levels of lactate dehydrogenase were consistently lower in the NIC-supplemented medium (Fig. 3).

DNA synthesis and $\beta$-cell function. Culture of ICCs for $7 \mathrm{~d}$ with various concentrations of NIC led to a dose-dependent increase in insulin content and basal insulin release. Consequently, the ratio of insulin release to content remained unchanged. The response was threefold at $20 \mathrm{mM}$ NIC. At least 5

Table I. Effect of Nicotinamide on the Development of ICCs during $7 d$ in Culture

\begin{tabular}{llll}
\hline & Control & Nicotinamide & $P$ \\
\hline & & $10 \mathrm{mM}$ & \\
& & & \\
$\begin{array}{l}\text { Number of ICCs/mg starting } \\
\text { tissue }\end{array}$ & $14.7 \pm 2.1$ & $21.8 \pm 1.4$ & 0.01 \\
Total DNA $(\mu \mathrm{g}) / \mathrm{mg}$ starting tissue & $0.40 \pm 0.04$ & $0.83 \pm 0.10$ & 0.001 \\
DNA/ICC $(\mathrm{ng})$ & $28.7 \pm 2.5$ & $39.2 \pm 5.6$ & 0.11 \\
$\begin{array}{l}\text { Total insulin }(\mathrm{pmol}) / \mathrm{mg} \text { starting } \\
\quad \text { tissue }\end{array}$ & $0.96 \pm 0.36$ & $3.19 \pm 0.70$ & 0.009 \\
\hline
\end{tabular}

Pieces of human fetal pancreas were weighed, digested, and cultured as described in Methods. After $7 \mathrm{~d}$, the ICCs were counted and harvested for measurement of insulin and DNA content. Data are the means $( \pm$ SEM) of 10 pancreases.
$\mathrm{mM}$ NIC was required for a significant effect on the insulin levels (Fig. 4). DNA synthesis was stimulated by NIC at a lower concentration range; $1 \mathrm{mM}$ concentration was sufficient for a significant increase, and the effect was maximal (2.4-fold) at $5 \mathrm{mM}$. Higher concentrations did not further increase the DNA synthesis. In fact, thymidine incorporation was significantly lower at $20 \mathrm{mM}$, as compared with 5 or $10 \mathrm{mM} \mathrm{NIC}$ (Fig. 4).
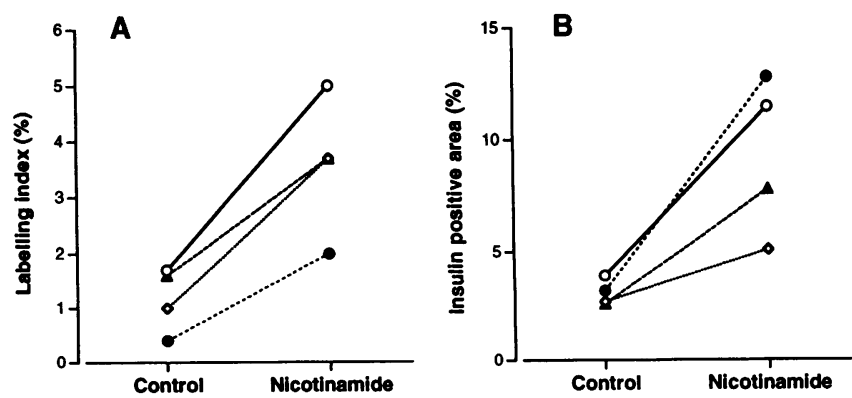

Figure 2. Morphometric analysis of immunohistochemically stained ICC sections. Labeling index (percent of BrdU-labeled nuclei, $A$ ) and surface area of insulin-positive cytoplasm (expressed as percent of total cell area, $B$ ) are shown for four separate experiments. At least 1,200 nuclei and 10 ICCs were evaluated for the determination of each value. 


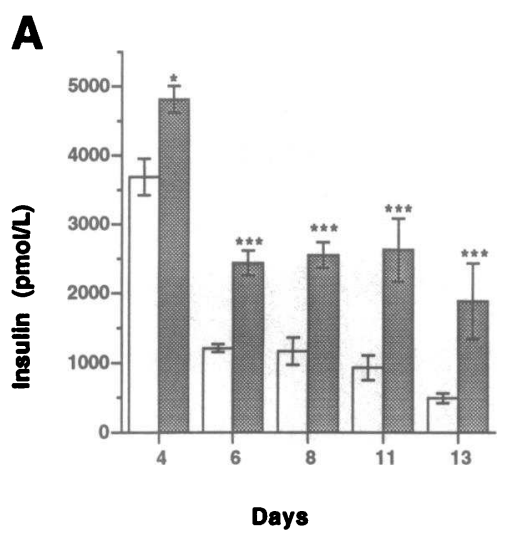

B

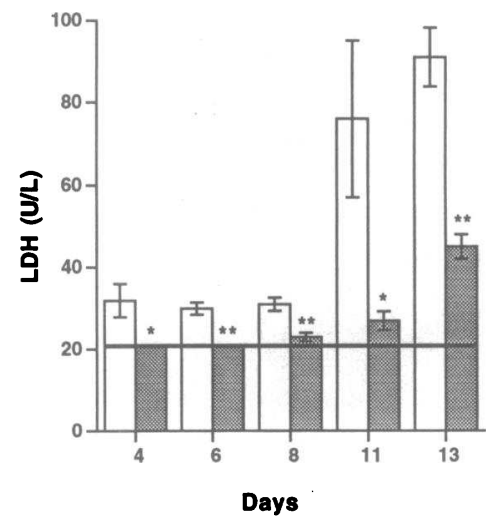

Figure 3. Content of insulin $(A)$ and lactate dehydrogenase $(B)$ in the culture medium of fetal ICCs during a 13-d culture period in standard medium (open columns) or with $10 \mathrm{mM}$ NIC (filled columns). Data are the mean \pm SEM for five groups of 50 ICCs cultured in tissue culture wells in $1 \mathrm{ml}$ of medium since day 2 . Media were changed at 2-3 d intervals and frozen for insulin and lactate dehydrogenase assays. The ICCs attached to the bottom of the dish and started to form a monolayer by day 5 . Fibroblast overgrowth was evident after $11 \mathrm{~d}$. In $B$, the detection limit of the LDH assay is denoted by the horizontal line. ${ }^{*} P<0.05 ;{ }^{* *} P$ $<0.01 ;{ }^{* * *} P<0.001$, as compared with control using Mann-Whitney $U$ test.
In control cultures, monolayer formation was accompanied by a marked increase in the rate of DNA synthesis and a decrease in the insulin release after $7 \mathrm{~d}$ (Table II). Insulin content was also decreased, but to a lesser extent. The presence of contaminating fibroblasts hampers the interpretation of results. Nevertheless, it is evident that monolayer-cultured $\beta$ cells were in a different functional state, characterized by a $70 \%$ lower fractional insulin release rate, as compared with the ICCs ( 3.5 vs $12.3 \%$, Table II). The fractional insulin release of monolayers cultured with NIC was closer to that of the ICCs (9.2 vs $12.1 \%$ ), possibly reflecting preservation of a higher level of $\beta$ cell differentiation (Table II). Contrary to the results in suspension culture, NIC mainly induced the growth of noninsulin containing cells in the monolayer, as judged by a doubling of the DNA content and a decrease in the insulin content per DNA (Table II).

The acute insulin response of ICCs cultured for $7 \mathrm{~d}$ either in control medium or with $10 \mathrm{mM}$ NIC was tested in a perifusion system. Insulin release from control ICCs was unresponsive to glucose alone, whereas the combination of $16.7 \mathrm{mM}$ glucose and $10 \mathrm{mM}$ theophylline induced a prompt response (Fig. 5 $A$ ). In contrast, ICCs cultured with NIC had a significant fourfold first-phase glucose response. Although attenuated, there was also evidence of a second-phase response (Fig. $5 B$ ).

To determine whether the effects of NIC could be reproduced with other poly (ADP-ribose) synthetase inhibitors, the ICCs were cultured with $10 \mathrm{mM}$ benzamide or $10 \mathrm{mM}$ 3-aminobenzamide, in parallel with $10 \mathrm{mM}$ NIC. Benzamide had an even stronger stimulatory effect on the insulin levels than NIC,
A

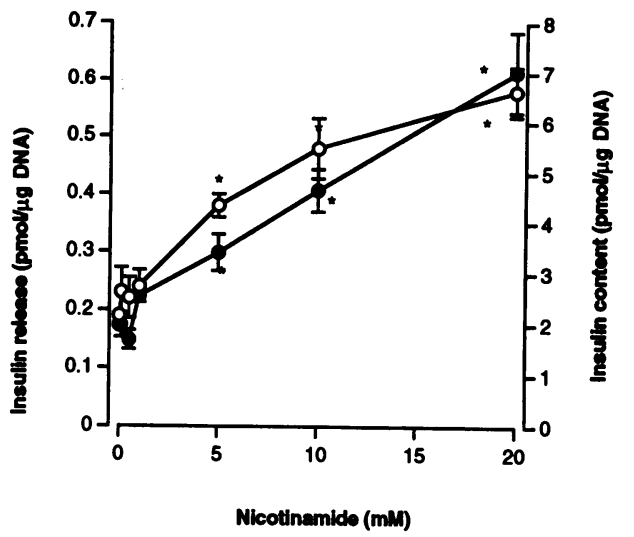

B

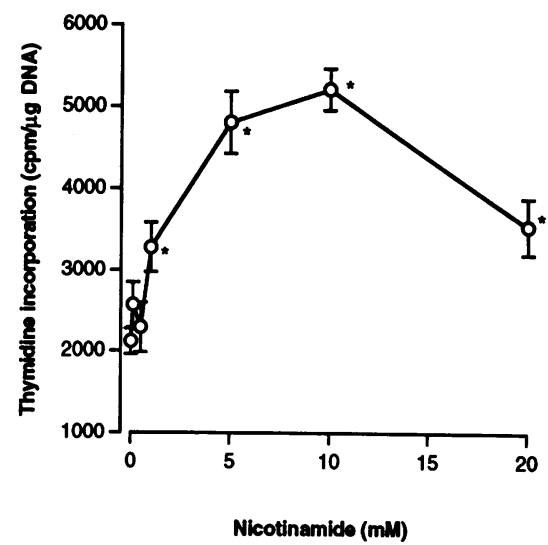

Figure 4. Response of insulin release $(0)$ and content $(\bullet, A)$ and DNA synthesis $(B)$ to varying levels of NIC in the culture medium during a 7-d culture period. Data are the mean \pm SEM of $10-15$ replicates from three separate experiments. Insulin release and thymidine incorporation were measured during the last $16 \mathrm{~h}$ as described in the Methods. ${ }^{*} P<0.05$, as compared with the control medium (containing $8 \mu \mathrm{M}$ NIC) using one factor ANOVA and Fisher's PLSD test.

whereas 3-aminobenzamide only stimulated the DNA synthesis but did not affect insulin content (Table III).

Islet hormone gene expression. Insulin and glucagon mRNAs were abundantly present in the ICCs, whereas the level of somatostatin mRNA was clearly lower. The somatostatin transcripts were seen as two protected bands. NIC increased the transcriptional levels of all three hormones, but there was no obvious regulation of cyclophilin mRNA by NIC (Fig. 6). After normalization against cyclophilin expression, the densitometrically determined mean fold increases were 1.8 ( range $=1.4-2.8), 1.7($ range $=1.3-2.9)$, and 1.7 (range $=1.1-2.2$ ) for insulin, glucagon and somatostatin, respectively $(P<0.05$ for all effects, Student's one-sample $t$ test, $n=5)$.

Graft development. Human C peptide could be detected in the serum of nude mice 3-5 mo after transplantation of 500 control or NIC-treated ICCs under the kidney capsule. In animals receiving control ICCs, there was a 5.1-fold increase in the C peptide level 30 min after an intraperitoneal glucose challenge. The difference in responses between animals receiving control and NIC-treated ICCs was not statistically significant. Basal C peptide levels were also similar in both groups ( Fig. 7). 
Table II. Effect of Tissue Culture Method (ICC vs. Monolayer) and Nicotinamide on DNA Synthesis and $\beta$ Cell Function

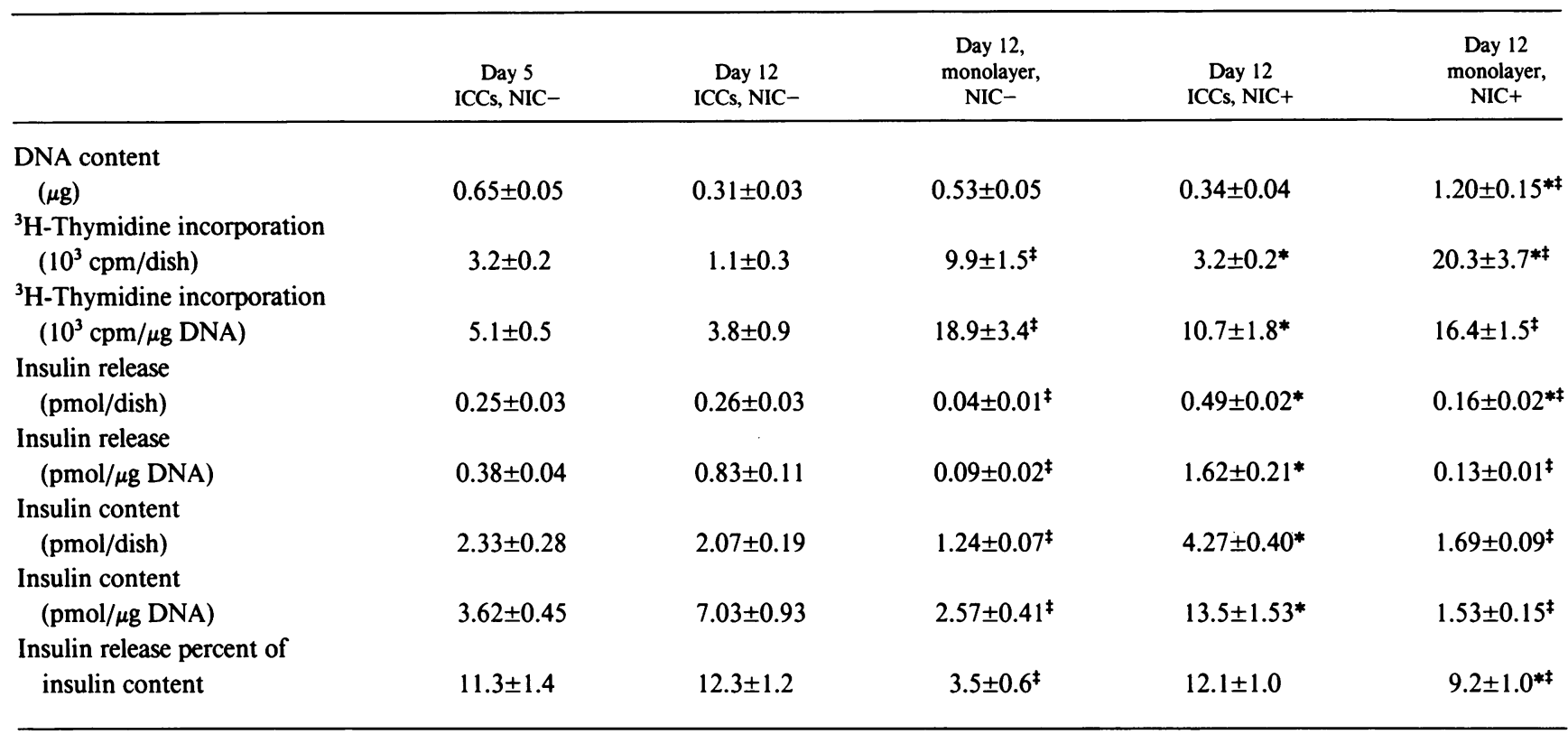

After $4 \mathrm{~d}$ in culture, groups of 50 ICCs originating from three pancreases were collected either in culture well inserts, where they remained in suspension, or on ECM-coated dishes to form a monolayer. Insulin release and thymidine incorporation were recorded during a 16-h incubation either immediately (day 5) or $7 \mathrm{~d}$ later (day 12). Data are the mean \pm SEM for eight replicates. Statistical significances using one-way ANOVA and Fischer’s PLSD test: * Significance level $\leq 95 \%$ when compared with the same culture method without NIC. ${ }^{\ddagger}$ Significance level $\leq 95 \%$ when compared with ICCs cultured in the same medium.

Grafts of NIC-treated and control ICCs were morphologically similar, consisting of endocrine and ductal tissue. We have shown previously that $85 \%$ of the surface area of histological sections cut through the control grafts was immunoreactive when exposed to a cocktail of antibodies against the four islet hormones (insulin, glucagon, somatostatin, and pancreatic polypeptide) (Beattie, G. M., F. Levine, M. I. Mally, T. Otonkoski, J. S. O'Brien, and A. Hayek, manuscript submitted for publication.)

Effects on adult human islets. The insulin content per cellular DNA of the adult islets was comparable to previously published data (26). When cultured for $7 \mathrm{~d}$ with $10 \mathrm{mM}$ NIC, the DNA content of the islets was increased by $62 \%$ (Table IV). DNA synthesis, as measured by $\left[{ }^{3} \mathrm{H}\right]$ thymidine incorporation, was $\sim 30 \%$ of the level observed in fetal ICCs, and it tended to be increased by NIC. The insulin content per cellular DNA of the adult islets was 40 times higher than in the fetal ICCs. In contrast to the experiments with fetal cells, the insulin content was similar in the two groups, and the insulin release was significantly lower in islets cultured with $10 \mathrm{mM}$ NIC (Table IV).

\section{Discussion}

Our experiments show that addition of NIC to the culture medium of human fetal pancreatic cells both increases the total cell number and the frequency of $\beta$ cells. Thus, the total number of $\beta$ cells is increased by NIC. This could be caused either by the formation of new $\beta$ cells through differentiation or by increased survival of the $\beta$ cells that were originally present. Our morphological observations strongly support the former possibility. The development of insulin-positive outgrowths from the undifferentiated epithelial cell clusters closely resembles the islet neogenesis that has been described in the rodent pancreas both in vivo (27) and in vitro (28). The observed increases in the transcription of the islet hormone genes by NIC, and the NIC-induced maturation of glucose-induced in-

Table III. Effects of Poly (ADP-ribose) Synthetase Inhibitors on $\beta$ Cell Function and DNA Synthesis of Human Fetal Islet-like Cell Clusters after $7 d$ in Culture

\begin{tabular}{|c|c|c|c|c|}
\hline & $\begin{array}{l}{\left[{ }^{3} \mathrm{H}\right] \text { thymidine }} \\
\text { incorporation }\end{array}$ & Insulin release & Insulin content & $\begin{array}{l}\text { Insulin release } \\
\text { percent of content }\end{array}$ \\
\hline & $c p m / \mu g D N A$ & 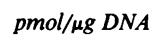 & 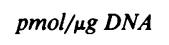 & \\
\hline Control & $1,884 \pm 342$ & $0.16 \pm 0.02$ & $1.97 \pm 0.33$ & $8.4 \pm 1.0$ \\
\hline Nicotinamide $10 \mathrm{mM}$ & $5,016 \pm 205^{\S}$ & $0.35 \pm 0.08^{*}$ & $4.26 \pm 0.4^{\ddagger}$ & $8.0 \pm 1.1$ \\
\hline Benzamide $10 \mathrm{mM}$ & $3,346 \pm 476^{*}$ & $0.72 \pm 0.13^{\ddagger}$ & $9.98 \pm 1.21^{\S}$ & $7.1 \pm 0.6$ \\
\hline 3-Aminobenzamide $10 \mathrm{mM}$ & $6,178 \pm 753^{\ddagger}$ & $0.51 \pm 0.1^{*}$ & $3.27 \pm 0.99$ & $17.0 \pm 2.5^{*}$ \\
\hline
\end{tabular}

Insulin release and thymidine incorporation were measured during the last $16 \mathrm{~h}$. Data are the mean $\pm \mathrm{SEM}$ of four replicate groups of 50 ICCs. ${ }^{*} P<0.05$ vs control; ${ }^{\ddagger} P<0.01$ vs control; ${ }^{\S} P<0.001$ vs control; two-tailed $P$ values for unpaired Student's $t$ test. 


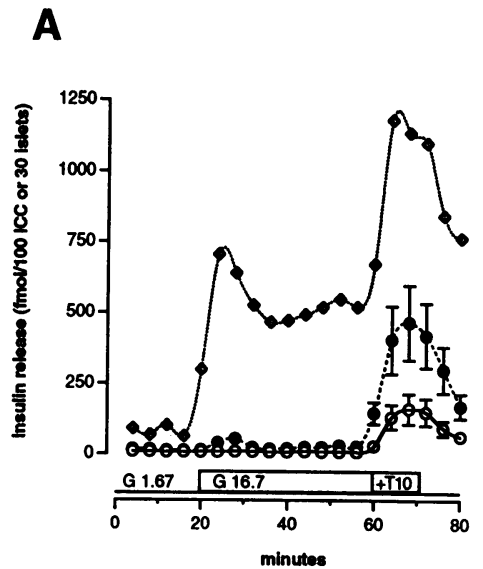

B

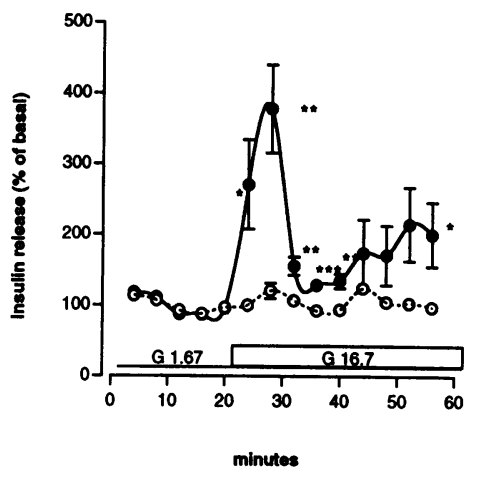

Figure 5. Insulin release in perifusion of adult islets $(\diamond)$ or fetal ICCs cultured for $7 \mathrm{~d}$ in standard medium $(0)$ or 10 mM NIC medium (•). $A$, expressed in absolute units, shows the response to sequential stimulation with 16.7 mM glucose (G16.7) and $10 \mathrm{mM}$ theophylline (T10). Insulin release from NIC-treated ICCs is significantly higher than in the control ICCs throughout the experiment. $B$ shows only the glucose response of the fetal experiments expressed as percent changes from the prestimulatory basal level. Data are the mean of two separate experiments with adult islets and the mean $\pm S E M$ of six fetal experiments; very small error bars are not shown. ${ }^{*} P<0.05$; ${ }^{* *} P<0.01 ;{ }^{* * *} P$ $<0.001$, as compared with control using Student's two-sample $t$ test.

sulin secretion, further support the view that NIC induces true endocrine differentiation in the fetal pancreas. This is the first clear evidence for neogenesis of human insulin-producing cells in culture. Until now, it has not been possible to reproduce in human tissue the proliferation, differentiation, and maturation of $\beta$ cells that occurs during culture of the fetal rodent pancreas (29). The only previous study exploring the effects of NIC on cultured human fetal islets suggested an increase in $\beta$ cell mass, but no further conclusions could be drawn, possibly because of poor tissue viability (10).

The marked NIC-induced improvement in the glucose sensitivity of insulin release is interesting, because significant development of a glucose-induced insulin response from human fetal $\beta$ cells has been previously shown only after engraftment into nude mice $(30,31)$. Unlike fetal rat islets (32), tissue culture of the human fetal pancreas in the presence of high glucose does not induce glucose sensitivity (33). Growth hormone (34) and retinoic acid (35) may induce marginal improvement in the glucose sensitivity, but the effects have not been nearly as marked as that of NIC observed in this study.

In accordance with previous studies $(30,31)$, transplantation of the ICCs under the kidney capsule of nude mice resulted in maturation of glucose-induced insulin secretion, as judged by the serum human $\mathrm{C}$ peptide concentrations measured 3 mo after transplantation. However, the beneficial effect of NIC could no longer be demonstrated in vivo at this time. Our results would thus suggest that NIC-pretreatment of fetal islet cells for transplantation has only limited value in improving the functional end result of the graft. However, our data do not
A
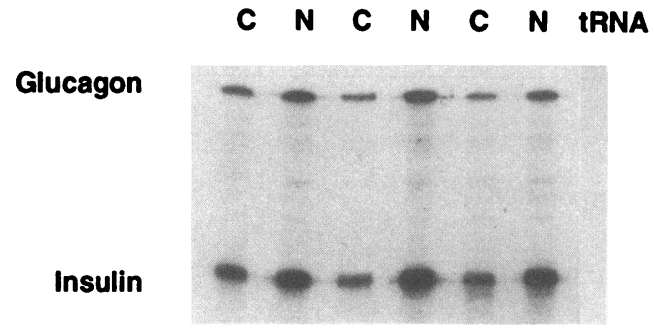

Cyclophilin

B

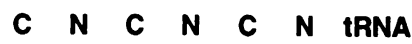

Somatostatin

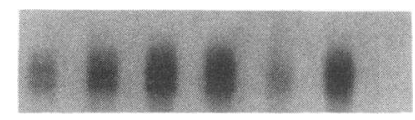

Cyclophilin

Figure 6. RNAse protection analysis of hormone transcripts in ICCs obtained from three pancreases and cultured for $7 \mathrm{~d}$ in the absence $(C)$ or presence $(N)$ of $10 \mathrm{mM}$ NIC. Total RNA (400 ng) was hybridized simultaneously to riboprobes for insulin, glucagon, and cyclophilin, or to somatostatin and cyclophilin, for $18 \mathrm{~h}$ at $56^{\circ} \mathrm{C}$, as described in Methods. Yeast transfer RNA (10 $\mu \mathrm{g})$ was used as a negative control. Protected fragments for insulin (262 nt), glucagon (389 nt), somatostatin (236 nt), and cyclophilin (135 nt) are indicated. Exposure times were $3 \mathrm{~h}$ for insulin and glucagon and $\mathbf{8 h}$ for somatostatin and cyclophilin.

exclude the possibility that NIC-treated grafts would have reached mature function earlier than the control grafts, as has been recently shown for fetal porcine islets (36). It should also be noted that we transplanted the same amount of control and NIC-treated tissue. Considering the NIC-induced increase in ICC formation, the total insulin-producing graft mass developing from a single pancreas may be increased by NIC pretreatment.

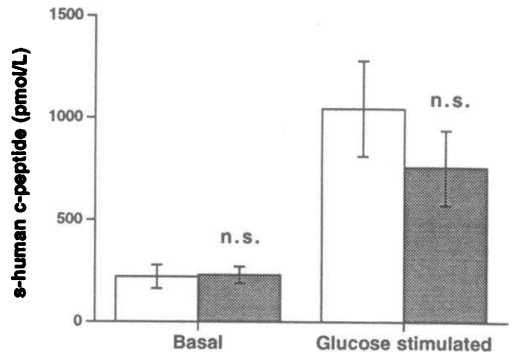

Figure 7. Basal and glucose-stimulated serum human $\mathrm{C}$ peptide levels measured in nude mice 3-5 mo after transplantation of 500 human fetal ICCs under the kidney capsule. Before transplantation, the ICCs were cultured for $7 \mathrm{~d}$ in the standard medium (open columns) or medium containing $10 \mathrm{mM}$ NIC (filled columns). Data are the mean \pm SEM of five observations. Human $C$ peptide was undetectable in mice that had not received human transplants (not shown). 
Table IV. Effects of Nicotinamide on Adult Human Islets

\begin{tabular}{|c|c|c|c|}
\hline & Control & Nicotinamide & $P$ \\
\hline DNA content (ng/islet) & $21.3 \pm 2.8$ & $34.6 \pm 2.9$ & 0.003 \\
\hline Insulin release (pmol/islet) & $0.21 \pm 0.01$ & $0.18 \pm 0.02$ & NS \\
\hline Insulin release $(\mathrm{pmol} / \mu \mathrm{g}$ DNA) & $11.3 \pm 1.3$ & $5.7 \pm 0.8$ & 0.001 \\
\hline Insulin content (pmol/islet) & $1.54 \pm 0.20$ & $2.05 \pm 0.23$ & NS \\
\hline $\begin{array}{l}\text { Insulin content (pmol/ } \mu \mathrm{g} \text { DNA) } \\
{\left[{ }^{3} \mathrm{H}\right] \text { Thymidine incorporation }}\end{array}$ & $82.7 \pm 11.3$ & $66.6 \pm 10.7$ & NS \\
\hline $\begin{array}{l}\text { (cpm/islet) } \\
{\left[{ }^{3} \mathrm{H}\right] \text { Thymidine incorporation }}\end{array}$ & $16.8 \pm 2.8$ & $31.2 \pm 5.7$ & NS \\
\hline$(\mathrm{cpm} / \mu \mathrm{g}$ DNA) & $911 \pm 181$ & $982 \pm 180$ & NS \\
\hline
\end{tabular}

The islets were cultured for $7 \mathrm{~d}$ either in RPMI medium $(5.6 \mathrm{mM}$ glucose and $10 \%$ human serum) alone, or with $10 \mathrm{mM}$ nicotinamide. Insulin release and $\left[{ }^{3} \mathrm{H}\right]$ thymidine incorporation were recorded during the last $16 \mathrm{~h}$. Data are the means $( \pm$ SEM) of 15 replicates of 50 islets from three pancreases.

In contrast with the results of Simpson and Tuch (37), we found that monolayer culture of the ICCs was associated with a decrease, and not an increase, in insulin production. This is in accordance with the general view that increased cell proliferation in vitro is inversely proportional to the stage of differentiation, which is also true for insulinoma cell lines (38). It is noteworthy that NIC treatment induced a simultaneous increase in the rate of DNA synthesis and the level of endocrine differentiation. However, it is evident that the DNA synthesis was mainly stimulated in the undifferentiated cells, whereas the BrdU labeling of hormone-containing islet cells was undetectable. This would suggest that NIC triggered a process in the uncommitted epithelial cells, which eventually resulted in the expression of an islet cell phenotype. Thus, the observed insulinotropic effects of NIC would mainly be caused by proliferation and differentiation of precursor cells, rather than a mitogenic effect on existing $\beta$ cells. The functional maturation of the cells also supports this view.

Based on these observations, the effects of NIC should be different in the adult islets, because they consist mainly of fully differentiated endocrine cells. In our experiments, the DNA content of the adult islets was increased by NIC, suggesting a stimulatory effect on cell proliferation. However, in contrast to the fetal cells, this was accompanied by impairment of insulin release. These results are in good agreement with previous studies on adult rat islets, where increased cell replication was associated with adverse effects on $\beta$ cell function, specifically insulin release (8). If the insulinotropic action of NIC was mainly caused by differentiation of undifferentiated islet precursor cells, which are presumably located within the ductal epithelium (39), it would be understandable that this effect could not be detected in the isolated islets. It is not clear, whether islet cell neogenesis from such precursor cells could contribute significantly to the islet cell mass in the adult pancreas. However, this is one of the possible mechanisms to explain the beneficial effects of NIC on the preservation of insulin secretion in experimental diabetes and in prediabetic individuals.

The effects of NIC could be reproduced with two other inhibitors of poly (ADP-ribose) synthetase, benzamide, and 3aminobenzamide (40), suggesting that decreased activity of this enzyme was the direct cause of the observed changes. The activity of poly(ADP-ribose) synthetase is linked with the level of cellular differentiation in several cell types. Evidence for this comes from experiments with preadipocytes (41), intestinal epithelial cells (42), chondrocytes (43), teratocarcinoma cells (44), and thymocytes (45). In all of these cells, the ADP-ribosylating activity is lower in the more differentiated phenotype, and morphological evidence of differentiation is preceded by diminished activity of poly(ADP-ribose) synthetase. Furthermore, chondrocyte and teratocarcinoma cell differentiation can be triggered by inhibitors of the enzyme, such as NIC and 3 -aminobenzamide $(44,46)$. These effects are likely to reflect changes in the ADP ribosylation of nuclear proteins, resulting in modifications in chromatin structure that enable the transcription of previously masked regions of DNA. However, the precise genes responsible for differentiation remain elusive.

In addition to insulin, the transcriptional levels of two other islet hormones, glucagon and somatostatin, were also induced by NIC. This is in accordance with an action on the putative pluripotent islet stem cell. All four islet hormones are thought to arise from a common precursor, as evidenced by cell lineage analysis (47). Cells expressing insulin together with glucagon, somatostatin, or pancreatic polypeptide can be detected after day 10 of mouse fetal development (47), and such mixed cell types have recently also been identified in the midgestational human fetal pancreas (48).

In summary, we have shown that morphological and functional differentiation of human pancreatic $\beta$ cells can be induced by NIC in tissue culture of human fetal pancreas rich in undifferentiated cells. Thus, this tissue culture model may be useful in further studies to dissect the molecular mechanisms of islet cell differentiation. Although it is difficult to assess the possible clinical implications of our in vitro findings, NIC treatment of fetal islet cells intended for transplantation may increase the functional graft mass. Also, increased neogenesis of $\beta$ cells should be considered as a possible mechanism for the reported beneficial effect of NIC on the preservation of insulin secretion (14). Further studies in vivo are required to clarify this issue.

\section{Acknowledgments}

We thank Ana Lopez for expert technical assistance and Fred Levine for helpful criticism of the manuscript. This study was supported by the National Institute of Digestive grant RO1-DK 39087, The Charles H. and Anna S. Stern Foundation, The Herbert O. Perry Fund, The Deutz Family, The Sigrid Jusélius Foundation (T. Otonkoski), and The Paulo Foundation (T. Otonkoski).

\section{References}

1. Uchigata, Y., H. Yamamoto, H. Nagai, and H. Okamoto. 1983. Effect of poly(ADP-ribose) synthetase inhibitor administration to rats before and after injection of alloxan and streptozotocin on islet proinsulin synthesis. Diabetes. 32:316-318.

2. Yamada, K., K. Nonaka, T. Hanafusa, A. Miyazaki, H. Toyoshima, and S. Tarui. 1982. Preventive and therapeutic effects of large-dose nicotinamide injections on diabetes associated with insulitis. Diabetes. 31:749-753.

3. Okamoto, H. 1984. Molecular basis of experimental diabetes: degeneration, oncogenesis and regeneration of pancreatic B-cells of islets of Langerhans. Bioessays. 2:15-21.

4. LeDoux, S. P., C. R. Hall, P. M. Forbes, N. J. Patton, and G. L. Wilson. 1988. Mechanisms of nicotinamide and thymidine protection from alloxan and streptozotocin toxicity. Diabetes. 37:1015-1019.

5. Yamada, K., E. Miyajima, and K. Nonaka. 1990. Inhibition of cytokine-induced MHC class II but not class I molecule expression on mouse islet cells by niacinamide and 3-aminobenzamide. Diabetes. 39:1125-1130.

6. Yonemura, Y., T. Takashima, K. Miwa, I. Miyazaki, H. Yamamoto, and 
H. Okamoto. 1984. Amelioration of diabetes mellitus in partially depancreatized rats by poly (adp-ribose) synthetase inhibitors. Diabetes. 33:401-404.

7. Sugiyama, K., Y. Yonemura, and H. Okamoto. 1991. Effects of poly (ADPribose) synthetase inhibitor on B-cells of a canine pancreas after massive pancreatectomy. Int. J. Pancreatol. 8:85-95.

8. Sandler, S., and A. Andersson. 1986. Long-term effects of exposure of pancreatic islets to nicotinamide in vitro on DNA synthesis, metabolism and B-cell function. Diabetologia. 29:199-202.

9. Sandler, S., and A. Andersson. 1988. Stimulation of cell replication in transplanted pancreatic islets by nicotinamide treatment. Transplantation (Baltimore). 46:30-31.

10. Sandler, S., A. Andersson, O. Korsgren, J. Tollemar, B. Petersson, C.-G. Groth, and C. Hellerström. 1989. Tissue culture of human fetal pancreas. Effects of nicotinamide on insulin production and formation of islet-like cell clusters. Diabetes. 38(Suppl. 1):168-171.

11. Vague, P., R. Picq, M. Bernal, V. Lassman-Vague, and B. Vialettes. 1989. Effect of nicotinamide treatment on the residual insulin secretion in type 1 (insulin-dependent) diabetic patients. Diabetologia. 32:316-321.

12. Mendola, G., R. Casamitjana, and R. Gomis. 1989. Effect of nicotinamide therapy upon B-cell function in newly diagnosed type 1 (insulin-dependent) diabetic patients. Diabetologia. 32:160-162.

13. Lewis, C. M., D. M. Canafax, J. M. Spra fka, and J. J. Barbosa. 1992. Double-blind randomized trial of nicotinamide on early-onset diabetes. Diabetes Care. 15:121-123.

14. Elliott, R. B., and H. P. Chase. 1991. Prevention or delay of type 1 (insulin-dependent) diabetes mellitus in children using nicotinamide. Diabetologia 34:362-365.

15. Chase, P., J. Dupre, J. Mahon, R. Ehrlich, E. Gale, H. Kolb, E. Lampeter, and J. Nerup. 1992. Nicotinamide and prevention of diabetes. Lancet. 339:10511052.

16. Otonkoski, T., M. Knip, P. Panula, S. Andersson, I. Wong, H. Goldman and O. Simell: 1988. Morphology, yield and functional integrity of islet-like cell clusters in tissue culture of human fetal pancreata obtained after different means of abortion. Acta Endocrinol. 118:68-76.

17. Beattie, G. M., D. A. Lappi, A. Baird, and A. Hayek. 1991. Functional impact of attachment and purification in the short term culture of human pancreatic islets. J. Clin. Endocrinol. \& Metab. 73:93-98.

18. Ricordi, C., P. E. Lacy, E. H. Finke, B. J. Olack, and D. W. Scharp. 1988 Automated method for isolation of human pancreatic islets. Diabetes. 37:413420.

19. Latif, Z. A., J. Noel, and R. Alejandro. 1988. A simple method of staining fresh and cultured islets. Transplantation (Baltimore). 45:827-830.

20. Erber, W. N., and D. Y. Mason. 1987. Immunoalkaline phosphatase labeling of terminal transferase in hematologic samples. Am. J. Clin. Pathol. 88:43-50.

21. Sternberger, L. A., P. H. Hardy, J. J. Cuculis, and H. G. Meyer. 1970. The unlabeled antibody method of immunohistochemistry. Preparation and properties of soluble antigen-antibody complex (horseradish peroxidase-antiperoxidase) and its use in identification of spirochetes. J. Histochem. Cytochem. 18:315-333.

22. Hinegardner, R. T. 1971. An improved fluorometric assay for DNA. Anal Biochem. 39:197-201.

23. Otonkoski, T., S. Andersson, M. Knip, and O. Simell. 1988. Maturation of insulin response to glucose during human fetal and neonatal development Diabetes. 37:286-291.

24. Singer, P. A., R. S. Balderas, and A. N. Theofilopoulos. 1990. Thymic selection defines multiple $\mathrm{T}$ cell receptor $\mathrm{V} \beta$ 'repertoire phenotypes' at the CD4/ CD8 subset level. EMBO (Eur. Mol. Biol. Organ.) J. 9:3641-3648.

25. Chomczynski, P., and N. Sacchi. 1987. Single-step method of RNA isolation by guanidium thiocyanate-phenol-chloroform extraction. Anal. Biochem. 162:156-159.

26. Eizirik, D. L., G. S. Korbutt, and C. Hellerström. 1992. Prolonged exposure of human pancreatic islets to high glucose concentrations in vitro impairs the $\beta$ cell function. J. Clin. Invest. 90:1263-1268.
27. Pictet, R., and W. J. Rutter. 1972. Development of the embryonic endocrine pancreas. In Handbook of Physiology. Section 7: Endocrinology. D. Steiner and N. Freinkel, editors. Williams and Wilkins, Baltimore, MD. pp. 25-66

28. Dudek, R. W., N. Freinkel, N. J. Lewis, C. Hellerstrom, and R. C. Johnson. 1980. Morphologic study of cultured pancreatic fetal islets during maturation of the insulin stimulus-secretion mechanism. Diabetes. 29:15-21.

29. Hellerstrom, C., N. J. Lewis, H. Borg, R. Johnson, and N. Freinkel. 1979. Method for large-scale isolation of pancreatic islets by tissue-culture of fetal rat pancreas. Diabetes. 28:766-769.

30. Tuch, B. E., A. Jones, and J. R. Turtle. 1985. Maturation of the response of human fetal pancreatic explants to glucose. Diabetologia. 28:28-31.

31. Hullett, D. A., K. P. Bethke, A. S. Landry, D. K. Leonard, and H. W. Sollinger. 1989. Successful long-term cryopreservation and transplantation of human fetal pancreas. Diabetes. 38:448-453.

32. Dudek, R. W., T. Kawabe, J. E. Brinn, K. O'Brian, M. C. Poole, and C. R. Morgan. 1984. Glucose affects in vitro maturation of fetal rat islets. Endocrinology. 114:582-587

33. Otonkoski, T., M. Knip, I. Wong, and O. Simell. 1991. Lack of glucose-induced functional maturation during long-term culture of human fetal islet cells. Life Sci. 48:2157-2163.

34. Otonkoski, T., M. Knip, I. Wong, and O. Simell. 1988. Effects of growth hormone and insulin-like growth factor 1 on endocrine function of human fetal islet-like cell clusters during long-term tissue culture. Diabetes. 37:1678-1683.

35. Tuch, B. E., and K. J. Osgerby. 1990. Maturation of insulinogenic response to glucose in human fetal pancreas with retinoic acid. Horm. Metab. Res. 25(Suppl.):233-238.

36. Korsgren, O., A. Andersson, and S. Sandler. 1993. Pretreatment of fetal porcine pancreas in culture with nicotinamide accelerates reversal of diabetes after transplantation to nude mice. Surgery (St. Louis). 113:205-214.

37. Simpson, A., B. Tuch, and P. Vincent. 1991. Characterization of endocrine-rich monolayers of human fetal pncreas that display reduced immunogenicity. Diabetes. 40:800-808.

38. Philippe, J., D. J. Drucker, W. L. Chick, and J. F. Harbener. 1987. Transcriptional regulation of genes encoding insulin, glucagon, and angiotensinogen by sodium butyrate in a rat islet cell line. Mol. Cell. Biol. 7:560-563.

39. Dudek, R. W., I. E. Lawrence, Jr., R. S. Hill, and R. C. Johnson. 1991 Induction of islet cytodifferentiation by fetal mesenchyme in adult pancreatic ductal epithelium. Diabetes. 40:1041-1048.

40. Ueda, K., and O. Hayaishi. 1985. ADP-ribosylation. Ann. Rev. Biochem. 54:73-100.

41. Pekala, P. H., M. D. Lane, P. A. Watkins, and J. Moss. 1981. On the mechanism of preadipocyte differentiation. J. Biol. Chem. 256:4871-4876.

42. Porteous, J. W., H. M. Furneaux, C. K. Pearson, C. M. Lake, and A. Morrison. 1979. Poly(adenosine diphosphate ribose) synthetase activity in nuclei of dividing and non-dividing but differentiating intestinal epithelial cells. Biochem. J. 180:455-463.

43. Caplan, A. I., and M. J. Rosenberg. 1975. Interrelationship between poly (ADP-Rib) synthesis, intracellular NAD levels, and muscle or cartilage differentiation from mesodermal cells of embryonic chick limb. Proc. Natl. Acad. Sci. USA. 72:1852-1857.

44. Ohashi, Y., K. Ueda, O. Hayaishi, K. Ikai, and O. Niwa. 1984. Induction of murine teratocarcinoma cell differentiation by suppression of poly (ADP-ribose) synthesis. Proc. Natl. Acad. Sci. USA. 81:7132-7136.

45. Hoshino, J., G. Beckmann, and H. Kroger. 1992. Sensitivity in vitro of mature and immature mouse thymocytes to dexamethasone cytotoxicity and its correlation to poly ADP-ribosylation. Biochem. Int. 27:105-116.

46. Nishio, A., S. Nakanishi, J. Doull, and E. M. Uyeki. 1983. Enhanced chondrocytic differentiation in chick limb bud cell cultures by inhibitors of poly(ADP-ribose) synthetase. Biochem. Biophys. Res. Commun. 111:750-759.

47. Alpert, S., D. Hanahan, and G. Teitelman. 1988. Hybrid insulin genes reveal a developmental lineage for pancreatic endocrine cells and imply a relationship with neurons. Cell. 53:295-308.

48. De Krijger, R. R., H. J. Aanstoot, G. Kranenburg, M. Reinhard, W. J. Visser, and G. J. Bruining. 1992. The midgestational human fetal pancreas contains cells coexpressing islet hormones. Dev. Biol. 153:368-375. 